\title{
Den danska förebilden
}

\author{
Anders Frenander
}

Många organisationer och enskilda aktörer inom svenskt kulturliv - och kanske i synnerhet biblioteken - har länge blickat västerut för inspiration och förebilder. Allra först var det naturligtvis den amerikanska public library-organiseringen som väckte intresse. Valfrid Palmgren, den svenska bibliotekspionjären (som förresten gifte sig med en dansk och flyttade till Köpenhamn), besökte ju det stora landet $\mathrm{i}$ väster för drygt hundra år sedan för att studera hur ett för den tiden helt modernt bibliotek skulle kunna formas och arbeta. All sådan inspiration var välbehövlig för ett svenskt biblioteksväsende, som nog knappast förtjänade namnet. Vid förra sekelskiftet fanns det förvisso en hel del bibliotek i landet. Men de flesta var små, mycket små. Många av dem hade bildats i anknytning till folkrörelsernas (arbetar-, nykterhets- och frikyrkorörelsernas) studieverksamhet och omfattade kanske bara ett par hyllor i en fackföreningslokal eller i en ordensloge. På några håll fanns stiftsbibliotek, som hade anor flera hundra år tillbaka i tiden, lokaliserade i anslutning till stiftsstädernas katedralskolor. I de stora städerna fanns förstås större bibliotek av mer publik karaktär, ett exempel är Göteborg, där det "Dicksonska folkbiblioteket" hade startas 1861 av den liberale filantropen James Dickson. Men generellt sett var standarden låg, bestånden små och de som skötte verksamheten hade egentligen mycket liten kunskap om vad bibliotek kunde vara

Anders Frenander, seniorprofessor Högskolan i Borås, Biblioteks- och informationsvetenskap,anders.frenander@hb.se och hur de kunde organiseras. Behovet av kunskap, goda exempel och fräscha idéer var stort (Hansson 1998, Torstensson, 1996).

Det var detta behov Valfrid Palmgren tog på sig att försöka fylla genom sin studieresa till USA hösten 1907. Men kanske åkte hon onödigt långt bort? Fanns det möjligen utmärkta exempel på betydligt närmare håll? Vid ett studium av svensk bibliotekshistoria uppenbarar sig nämligen flera exempel på att det enda vatten man hade behövt korsa var Öresund, inte Atlanten. Vid flera tillfällen i utredningar och analyser av hur det svenska biblioteksväsendet skulle organiseras, arbeta och utvecklas, återkommer referenserna till det danska systemet.

Palmgrens reserapport, Bibliotek och folkuppfostran - anteckningar från en studieresa i Amerikas Förenta Stater, kom ut 1909 och ledde bland annat till att hon fick i uppdrag att ensam utreda hur folkbiblioteksrörelsen skulle kunna främjas. I denna, den första stora svenska biblioteksutredningen, använde hon, förutom sina nyvunna erfarenheter och kunskaper om de amerikanska public libraries, också en del idéer från Danmark för att ge exempel på hur svenska folkbibliotek skulle kunna arbeta. Fast hon ville att de skulle kallas "allmänna bibliotek" - precis som de amerikanska. Just på namnfrågan fick hon ge sig, men flera andra av hennes förslag kom att genomföras genom riksdagsbeslutet 1912. Den viktigaste reformen var nog inrättandet av två så kallade bibliotekskonsulenter, som skulle inspirera och övervaka verksamheten, 
utbilda bibliotekarier och allmänt se till att folkbiblioteken blev en aktiv beståndsdel i "folkuppfostran".

Nästa stora utredning, efter Palmgrens egen, genomfördes på 1920-talet. De så kallade folkbildningssakkunniga publicerade 1924 betänkandet Det fria och frivilliga folkbildningsarbetet som ägnade mycken möda åt analys av hur folkbibliotekssystemen var ordnade i Danmark, Finland och Holland och konstaterade att det danska exemplet vore att föredra, eller på den tidens kanslisvenska: " ... ansluta sig de sakkunniga för sin del i princip till det danska systemet" (SOU 1924:5, s. 43). Denna entusiasm gällde, föreföll det, alla sidor av hur man arbetade i Danmark. Den utbildning som bedrevs vid Danmarks Biblioteksskole sågs som ett efterföljansvärt exempel på hur bibliotekarieutbildning borde organiseras och strukturen med centralbibliotek som noder i ett landsomfattande biblioteksnät var också mycket bra, menade man.

Det var inte bara officiella utredningar som gillade hur danskarna formade sina folkbibliotek. Samma positiva syn delades av många aktiva ute på fältet. I en kommentar till ovan nämnda betänkande publicerad i Biblioteksbladet (som startades av Sveriges Allmänna Biblioteksförening 1916) konstaterades med gillande att sakkunniga "i mycket stor utsträckning tillgodogjort sig de erfarenheter som vunnits under de senaste årens synnerligen framgångsrika arbete $\mathrm{i}$ vårt grannland Danmark" (BBL 1924:2, s. 38). Jag tror att man kan hitta många fler exempel på sådan entusiasm (ibland bemängd med ett uns avund) inför hur saker och ting var ordnade i Danmark när det gällde folkbiblioteken. I början av 1960-talet, när de svenska folkbibliotekens förutsättningar fördes högt upp på den kulturpolitiska agendan, påpekade bibliotekskonsulenten Bengt Hjelmqvist att "Danmark har alltid legat före oss" (BBL 1961:7, s. 492). Hans ord kom, med varierande grad av bitterhet gentemot regeringens njugghet, att upprepas av många debattörer under sextiotalet.

Möjligen upphörde denna kritiska syn på de svenska politikernas ovilja att se ut över Öresund och ta efter utvecklingen i vårt grannland just på 1960-talet. Det var nämligen den period i svensk politik då kulturfrågorna i allmänhet och folkbiblioteken i synnerhet kom att engagera både regeringen och många kulturdebattörer. Och många konkreta beslut fattades. Både på nationell och på lokal nivå, med den följden att inte bara de svenska folkbiblioteken fick ett starkt uppsving i sin verksamhet, utan att också en nationell kulturpolitik formades. Många, inklusive politiker, biblioteksfolk och kulturarbetare, såg dessa reformer som en sorts fullbordande av den svenska välfärdsmodellen, Folkhemmet.

Men det är klart. Helt utan att snegla på det danska exemplet genomfördes förstås inte denna process. Danmark låg lite före. Där hade Kulturministeriet inrättats 1961, som det andra i Västeuropa (Frankrike var allra först, 1959). Det kom förvisso att dröja tre decennier innan man i Sverige fann för gott att skapa ett eget departement för kulturpolitiken, och en minister med just titeln kulturminister. I början av 1960-talet etablerades emellertid en kulturpolitisk avdelning inom ecklesiastikdepartementet, vilken kom att bidra starkt till hur kulturpolitikens område såväl som dess organisering utformades. Här kanske man kan säga att Sveriges och Danmarks vägar skiljdes åt en del. Den svenska kulturpolitiken blev faktiskt lite annorlunda än den danska. Men det är en annan historia.

Om de faktiska förhållandena i vårt sydvästra grannland alltså i flera avseenden låg, åtminstone tidsmässigt, före de svenska, är det kanske inte konstigt att också den danska forskningen kring kultur- och bibliotekspolitiska (i vid mening) frågor legat före sina svenska motsvarigheter? En forskare som var tidigt ute med att analysera kulturpolitiskt relevanta spörsmål, inklusive bibliotekens funktion och roll i samhället, var Dorte Skot-Hansen i Köpenhamn. På båda dessa områden har hon varit ett föredöme och inspirationskälla för svensk forskning på alla nivåer från studentuppsatser till avhandlingar och seniora projekt.

Dortes goda förmåga att spalta upp och sortera folkbibliotekens verksamhet, utan att förfalla till stelbenta och fyrkantiga "checklistor" har hjälpt många studenter att nå djupare förståelse av hur mångsidigt folkbibliotekens samhälleliga uppdrag är. De analysramar, som hon har utvecklat i samarbete med andra danska forskare, har också på ett kreativt sätt successivt anpassat sig till ett samhälle i omvandling. Det sättet att analysera - den modellen, om man så vill som hon har utvecklat i samarbete med andra danska forskare, har också på ett kreativt sätt successivt anpassat sig till ett samhälle i omvandling. Modellen är 
därför lika användbar när också biblioteken förändrar sin inställning och verksamhet.

Typiskt har de här analysramarna utformats som en fyrfältstabell där bibliotekens uppdrag varit utgångspunkten, ursprungligen formulerade som att biblioteket skulle fungera som ett informationscentrum, ett socialt centrum, ett kulturcentrum och ett centrum för kunskap i det lokala samhället (Andersson $\&$ Skot-Hansen, 1994). Till en början kunde modellen kanske uppfattas som en aning statisk: det här är uppdragets sammansättning, så här ser verksamheten ut. Modellen har dock efterhand utvecklats och blivit alltmer dynamisk. I sin senaste version, "the four-space model" som gör sig bäst på engelska, är uppdragen: empowerment, experience, innovation och involvement (Jochumsen, Hvenegaard Rasmussen \& Skot-Hansen, 2012). Här förenas ett individperspektiv med ett samhälleligt. Om "experience" och "involvement" berör den enskilda människans individuella strävanden, så handlar "empowerment" och "innovation" snarare om enskildas och gruppers försök att på olika sätt påverka samhällets utformning. Bibliotekets funktion går alltså att spåra både på mikro- och makronivå, och har, kan man säga, att göra med själva förbindelsen, interaktionen mellan individerna (enskilt eller i grupp) och samhället och dess institutioner och strukturer.

Men författarna - här har Dorte arbetet ihop med Henrik Jochumsen och Casper Hvenegaard Rasmussen - vill inte stanna vid att bara erbjuda en fruktbar analysmodell. Deras ambition är att också anvisa en vision för biblioteket, en idé om ett möjligt sätt att arbeta och utforma både den fysiska och virtuella verksamheten vid en modernt och framåtsyftande folkbibliotek, som vill ta de fyra uppdragen på allvar. Då uppdagas, enligt författarna, fyra "spaces" (återigen är översättning från engelskan besvärlig: på svenska skulle vi kanske tala om "utrymmen"?): "inspiration space", "learning space", "meeting space" och "performative space", vilka överlappar varandra såväl som att de "täcker in" flera av de uppdrag biblioteket har (ibid.).

Bakgrunden till denna utveckling av den ursprungliga modellen från början av 1990-talet är det framväxande och alltmer utmejslade "upplevelsesamhälle", som åtminstone i de rika delarna av världen kommit att karaktärisera många aspekter av människors vardagsliv. Om det är ett sådant vi lever i, med innebörden att vi alltmer söker, och vill betala för, upplevelser och att det också blir alltmer lukrativt att skapa, förpacka och sälja upplevelser som varor, så är det viktigt att biblioteken inte ställer sig bredvid en sådan utveckling. Med Dortes "four-space model" har vi en modell som går att använda både för analys av verksamheten och som vision för hur denna kan förändras. Genom att den är så listigt utformad blir den så mångsidig!

Bibliotek kan också användas som instrument. Det har naturligtvis länge varit det kanske främsta kulturpolitiska instrumentet på lokal nivå. På senare tid har det instrumentella emellertid sträckts allt längre bort från kulturlivet. Nu bygger man bibliotek för att stärka en orts attraktions- och konkurrenskraft, när det gäller att få särskilt kreativa näringar och människor att flytta till den. Bibliotek blir ikonbyggnader. Den här utvecklingen är förstås något som Dorte och hennes medarbetare forskat och skrivit om i många sammanhang. Den fantastiskt fina boken Biblioteket $i$ byudviklingen är det förnämsta exemplet.

Men den här artikeln ska inte handla om Dortes hela forskargärning; till det krävs betydligt större omfång. Det jag vill ta fasta på är, som nämnts, hennes föredöme och stora inspiration för svenska forskare. I det avseendet är hennes analyser av bibliotekets roll och funktion i samhället bara en del. En annan, minst lika viktig del, är hennes många kulturpolitiskt inriktade artiklar. En viktig fråga är förstås alltid vad är kulturpolitik? Hur kan den karaktäriseras? Vad omfattar den? Vad syftar den till? På vilka grunder går den att legitimera?

Också här kan vi lita till Dorte. I en ofta citerad artikel i Nordisk Kulturpolitisk Tidskrift (1999:1) har hon presenterat tre "rationaler" för hur kulturpolitik kan karaktäriseras och rättfärdigas. De tre benämns i tur och ordning "humanistisk", "sociologisk" och "instrumentell" och Dortes eminenta förmåga att sortera och skilja ut fenomen på ytan firar triumfer i det omfattande schema som byggs upp. Genom att ange åtta olika dimensioner i vilka rationalerna kan bestämmas kan de tre ges en precis idealtypisk innebörd. De åtta dimensionerna handlar om att identifiera ett övergripande mål med politiken; att ange mot vilken samhällelig bakgrund politiken i första hand ska agera; att peka ut på vilken politisk nivå den har sin förankring; att sammanfatta dess politiska ideologi, eller strategi; att avgöra vilken publik politiken riktar 
sig mot; att identifiera de institutionella och organisatoriska ramar som politiken utspelar sig i; att förstå vilken funktion politiken vill fylla i relation till medborgarna; och, slutligen, att peka på vilka de konkreta förmedlarna av politiken blir i vartdera fallet.

Sammantaget skapar schemat ett finmaskigt nät med vilket man kan söka, finna och karaktärisera 'reellt existerande' kulturpolitik på lokal, regional eller nationell nivå. Det fina med modellen är att den å ena sidan, teoretiskt och abstrakt, pekar ut tre idealtyper (som väl uppfyller Max Webers krav), men att den å andra sidan också medger, eller snarare uppmuntrar till att se de tre rationalerna på mera dynamiska vis. En uppenbar fördel är ju att det i en konkret analys är lätt att se en historisk följd i hur vissa dimensioner avlöser varandra. Men också, och samtidigt, hur dimensioner överlagrar varandra och bygger reella, konkreta kulturpolitiska formationer som innehåller fasetter av alla slags rationaler. Den mångsidiga modellen, igen!

Vår gemensamma forskarkollega Jenny Johannisson tog sig i sin avhandling från 2006 friheten att döpa om den tredje rationalen från "instrumentell" till "marknadsorienterad". Hennes argument för att göra det, menar jag är oomkullrunkeliga; all politik är i sig instrumentell, den är ett verktyg för att åstadkomma någon sorts förändring. Så även kulturpolitiken. Förvisso kan det handla om en ganska snäv användning av instrumentet, till exempel att få fler människor att ägna sig åt kultur, att bilda sig. Det är ju vad den humanistiska rationalen handlar om. Men en sådan terminologisk innovation tror jag inte att Dorte har något att invända mot.

Mycket mer finns att säga om vad Dorte har åstadkommit med sin forskning om kulturpolitiska ämnen och olika biblioteksanknuta frågor. Men det var inte syftet med den här artikeln, utan vad jag ville peka på var det föredöme och den inspiration hon utövat i Sverige. Otaliga är de studentuppsatser på Bibliotekshögskolan i Borås som använt sig av någon av de mångsidiga och dynamiska modeller och scheman Dorte utvecklat. Helt i hennes anda har många av dem kunnat skapa ny, inträngande och detaljerad kunskap om vad som pågår på kulturfältet. Men de teoretiska verktyg Dorte utvecklat har, som vi sett, gått långt bortom grundstudenternas ansträngningar. Och, vet jag med säkerhet, långt bortom Bibliotekshögkskolan i Borås väggar.
Så, om svenska kulturpolitiker och biblioteksanställda numera kanske inte lika ivrigt skådar över Öresund för att hitta inspiration och förebilder, gör vi svenska forskare ändå gärna det.

Tack Dorte!

\section{Referencer}

Andersson, M \& Skot-Hansen, D (1994). Det lokale bibliotek - avvikling eller udvikling. Köpenhamn: Danmarks Biblioteksskole og Udviklingscenteret for folkeoplysning og voksenundervisning.

Biblioteksbladet 1924:2.

Biblioteksbladet 1961:7.

Hansson, J (1998). Om folkbibliotekens ideologiska identitet: en diskursstudie. Borås: Högskolan i Borås/ Göteborgs universitet.

Hvenegaard, C, Jochumsen, H \& Skot-Hansen, D (2011). Biblioteket i byudviklingen: oplevelse, kreativitet og innovation. København: Danmarks Biblioteksforening.

Jochumsen, H, Hvenegaard, C \& Skot-Hansen, D (2012). The four spaces - a new model for the public library, New Library World, vol 113, no 11/12.

Johannisson, J (2006). Det lokala möter världen: kulturpolitiskt förändringsarbete i 1990-talets Göteborg, Borås: Valfrid.

Palmgren, V (1909). Bibliotek och folkuppfostran: anteckningar från en studieresa i Amerikas Förenta Stater, Stockholm: P.A. Norstedt \& Söners Förlag.

Skot-Hansen, D (1999). Kultur til tiden - strategier i den lokale kulturpolitik, Nordisk Kulturpolitisk Tidskrift, 1999:1.

Torstensson, M (1996). Att analysera genombrottet för de moderna folkbiblioteksidéerna: exemplet Sverige och några jämförelser med USA. Göteborg: Avdelningen för biblioteks och informationsvetenskap, Göteborgs universitet.

Statens Offentliga Utredningar 1924:5. Det fria och frivilliga folkbildningsarbetet, Stockholm. 